Vol. 8, Issue 8, August 2021

DOI: $10.17148 /$ IARJSET.2021.8830

\title{
Fathers Role Importance in Children's Life
}

\author{
Y. D. Haritha' ${ }^{1}$ Dr. Uma Devi ${ }^{2}$ \\ Department of Human Development And Family Studies, College of Community sciences, Acharya N. G. Ranga \\ Agricultural University
}

\begin{abstract}
A wonderful and healthy parenting is one which involves both mothers and fathers taking active participation in a child's life. Scientifically, it has been proven that children whose fathers have active involvement in their growing up years have fewer behavioural problems and turn out better individuals socially and academically. A father's role is not just limited to being a "breadwinner" for the family. His involvement influences the child's overall development, including the intellectual development, gender-role development, and psychological development. He can be just as loving and nurturing as the mother. Most kids who share an intimate and warm relationship with their fathers tend to grow up to become more confident adults. As children grow up, fathers assume the role of a friend, guide and mentor. The presence of an actively involved father at home goes on to make a lot of difference in the lives of children. "When fathers are actively involved with their children, children do better," explains Paul Amato, a sociologist who studies parent-child relationships at Pennsylvania State University. "Research suggests that fathers are important for a child's development." "The Father Effect" is the umbrella term for the benefits of a paternal presence. Of course, a father's active participation in the family is always preferred. "There needs to be a minimum amount of time spent together, but the quality of time is more important than the quantity of time." Here is a look at the roles fathers play at different stages of their child's life. Traditional Indian notions endorsed the fathers' role as a provider, protector, teacher and a moral guardian to children (Kane 1974; Krishnan, 1998). The present study makes an attempt to understand the Fathers Role Importance in Children's Life. The results revealed that 94 percent faced difficulties in fulfilling children's physical and psychological needs, 91 percent fathers Created a conducive environment for children's, 87 percent fathers Guided for future and making them independent, 81 percent fathers inculcated in good values, habits in children.
\end{abstract}

Keywords: Father, Role, Children

\section{INTRODUCTION:}

Fathers, like mothers, are pillars in the development of a child's emotional well-being. Children look to their fathers to lay down the rules and enforce them. They also look to their fathers to provide a feeling of security, both physical and emotional. Children want to make their fathers proud, and an involved father promotes inner growth and strength. Studies have shown that when fathers are affectionate and supportive, it greatly affects a child's cognitive and social development. It also instills an overall sense of well-being and self-confidence.

Most fathers in today's urban context in western India (Mumbai, Baroda, and Jaipur) expect an ideal father to be aware of and address the child's need, and be a friend, teacher and guide to the child (Saraff \& Srivastava, 2008).

In addition, fathers think it is their 'duty' to create a conducive environment for the child's growth, address their child's health needs, support both present but future security of the child, and maintain healthy loving and close relationships with children. Research studies with Indian fathers report a host of positive fathering Ideals such as guiding children's education, becoming more open, expressive, adopting less strict discipline measures, assigning more importance to children and their fathering role, prioritizing communication with their children, and engaging children in extracurricular activities (Mathur \& Mathur, 2006; Sandhu, 2008; Sriram, 2003, 2008).

Talking about the role of fathers in their children's development and well-being, it is important to define what is meant by "father" as the term carries several assumptions that may not be completely accurate given the changing family structure. In the AAP (American Academy of Pediatrician) guideline on fathers, father is defined broadly as "the male or males identified as most involved in caregiving and committed to the well-being of the child, regardless of living situation, marital status, or biological relation." Along with the biological father, this definition includes foster fathers, stepfathers, and grandfathers (Yogman M, Garfield CF, 2019).

Underlying this discussion of who is a father is the recognition of the evolving and changing nature of family structures, societal norms, and understanding of masculinity and femininity that is creating additional complexity to understanding the multiple influences on childhood development. Research shows that the influence of fathers on the psychosocial and behavioral development of children is distinct from that of mothers (Yogman M, Garfield CF, 2019). However, it is difficult to tease out of this current research how these different influences are related to the biological distinctiveness of masculinity or femininity. Emerging research on the neurobiology of parenting provides some preliminary signs by showing just how complex the interplay between hormonal and neural circuitry is in men and women and how these 


\title{
International Advanced Research Journal in Science, Engineering and Technology
}

\author{
Vol. 8, Issue 8, August 2021
}

\section{DOI: $10.17148 /$ IARJSET.2021.8830}

biological processes manifest differently in parenting behavior (Rajhans P, Goinâ, Kochel RP, Strathearn L., Kim S. 2019).

Benefits of fathers' early involvement: Data show that getting fathers involved early in their children's lives predicts later involvement. Prenatal involvement by fathers, along with living with the mother, is the strongest predictor of their involvement by the time a child is aged 5 years (Shannon JD, Cabrera NJ, Tamis-Lemonda C, Lamb ME. 2009)

Paternal involvement just after a child is born is also critical. "Good research shows that the more men take time to spend at home with a child after birth, 2 weeks or more, they are almost 2 times as likely to be involved in diapering, feeding, cleaning, and caring for their baby at 9 months," says Garfield (Nepomnyaschy L, Waldfogel J.2007).

Helping fathers to be more confident in taking care of their children helps their children during all stages of their development. Garfield highlights 3 main areas in which involvement by fathers is distinct from, and often complementary to, involvement by mothers.

One is in the area of language development. Garfield cites evidence showing that the more words and language to which a child is exposed at an early age, the greater benefit for kindergarten readiness. Children exposed to language and vocabulary through both mothers and fathers benefit by the additive effect of both hearing more words and also more variety Pancsofar N, Vernon-Feagans L. 2006).

Another way in which fathers uniquely contribute to early childhood development is by promoting more risk taking and problem-solving behavior through greater physical engagement with the child than is typically done by mothers. (Raeburn P. 2014, Yogman YW, Lester BM, Hoffman J. 1983). "Really unique to dads is in the general area of play and in particular what is called 'rough and tumble' play," says Garfield, describing this type of play as a very high-energy and physical game wherein fathers may be changing the rules during play forcing the child to adapt quickly to the changes Fletcher R, St George J, Freeman E. 2013). "It is thought that this is helping children learn about how to make decisions and how to stay focused when they are amped up," he says, "and that can actually be teaching resilience to the child as well."

Fathers also influence their children during early childhood years and into adolescence by role-modelling behavior. Garfield emphasizes the important influence of fathers as a role model for adolescent sons and daughters. "They are role modelling how to be in a relationship, how to make health and well-being behavior decisions, and that can be important for the child as well," he says. For example, longitudinal data show an association between father involvement and reduced behavioral problems and enhanced cognitive development in adolescent boys as well as reduced psychological problems in adolescent girls (Sarkadi A, Kristiansson R, Oberklaid F, Bremberg S. 2008) Other benefits of father involvement for adolescent girls are decreased early sexual experiences and teenaged pregnancy (Ellis BJ, Schlomer GL, Tilley EH, Butler EA. 2012) and for boys the potential for improvement in sexual health through better communication about condoms (Guilama-Ramos, V, Thimm-Kaiser M, Benzekri A, et al. 2019).

\section{RESEARCH METHOD:}

It focused on children ( 3 to 15 years). The main focus of the study was to study Fathers Role Importance in Children's Life.

Sample: $\mathrm{N}=(80)$

\section{RESEARCH FINDINGS AND DISCUSSION:}

In 2016, the American Academy of Pediatrics (AAP) updated its guidance for pediatricians on the role of fathers in the care and development of their children based on the increasing number of "high-quality" studies that now quantify and qualify this role. According to the guideline, among the drivers underlying this increased interest in fathers are socioeconomic forces in which the traditional roles of men and women are changing. More mothers are working outside the home and more stay-at-home fathers are taking on caregiving activities. Fathers also are increasingly taking on the primary caregiving role as single parents. Also highlighted are changing social mores encouraging more involvement by fathers beyond their historic protector and provider role. Data show this, with involvement by fathers in childcare nearly doubling between 1965 and 2011 (Parker K, Wang W. 2019).

The data collected with respect to understand the Fathers Role Importance in Children's Life. The results revealed that 94 percent faced difficulties in fulfilling children's physical and psychological needs, 91 percent fathers Created a conducive environment for children's, 87 percent fathers Guided for future and making them independent, 81 percent fathers inculcated in good values, habits in children.

$(\mathbf{n}=\mathbf{8 0})$

\begin{tabular}{|c|c|c|c|c|}
\hline \multirow{2}{*}{ S.no } & \multirow[t]{2}{*}{ Statements } & \multicolumn{3}{|c|}{ Total } \\
\hline & & Category & $\mathbf{F}$ & $\mathbf{P}$ \\
\hline \multirow[t]{2}{*}{1} & \multirow{2}{*}{$\begin{array}{l}\text { Faced difficulties in fulfilling children's physical and } \\
\text { psychological needs }\end{array}$} & Yes & 75 & 94 \\
\hline & & No & 5 & 6 \\
\hline \multirow[t]{2}{*}{2} & \multirow[t]{2}{*}{ Creating a conducive environment for children's } & Yes & 73 & 91 \\
\hline & & No & 7 & 9 \\
\hline
\end{tabular}


International Advanced Research Journal in Science, Engineering and Technology

Vol. 8, Issue 8, August 2021

DOI: $10.17148 /$ IARJSET.2021.8830

\begin{tabular}{|l|l|c|c|c|}
\hline 3 & Guiding for future and making them independent & Yes & 70 & 87 \\
\cline { 3 - 4 } & & No & 10 & 13 \\
\hline 4 & Inculcating good values, habits in children & Yes & 65 & 81 \\
\cline { 2 - 4 } & & No & 15 & 19 \\
\hline & & Total & $\mathbf{8 0}$ & $\mathbf{1 0 0}$ \\
\hline
\end{tabular}

\section{CONCLUSION:}

The data collected with respect to understand the Fathers Role Importance in Children's Life. The results revealed that 94 percent faced difficulties in fulfilling children's physical and psychological needs, 91 percent fathers Created a conducive environment for children's, 87 percent fathers Guided for future and making them independent, 81 percent fathers inculcated in good values, habits in children.

Creating opportunities for fathers to be more involved in the caretaking needs of their children is critical at a time when the changing mores and expectations of society are seeing more fathers involved in caregiving activities with their children. Growing evidence shows that fathers contribute to the development and well-being of their children in unique and often complementary ways to mothers.

\section{REFERENCES:}

1. Ellis BJ, Schlomer GL, Tilley EH, Butler EA. Impact of fathers on risky sexual behavior in daughters: a genetically and environmentally controlled sibling study. Dev Psychopathol. 2012;24(1):317-332.

2. Guilama-Ramos, V, Thimm-Kaiser M, Benzekri A, et al. Father-son communication about consistent and correct condom use. Pediatrics. 2019;143(1):e20181609.

3. Fletcher R, St George J, Freeman E. Rough and tumble play quality: theoretical foundations for a new measure of father-child interaction. Early Child Development and Care. 2013;183(6):746-759.

4. Kane, P. V. (1974). History of Dharmasastra. Ancient and medieval religious and civil law, (2nd ed., Vol. 2). Poona: Bhandarkar Institute Press.

5. Krishnan, L. (1998). Childrearing: The Indian perspective. In A.K. Shrivastava (Ed.) Child Development: The Indian Perspective. New Delhi: NCERT Press.

6. Mathur,M., \&Mathur, M.( 2006) Between Fathers and Children: Experiences and expectation of Indian adolescents. Unpublished master's dissertation, Department of Human Development, University of Rajasthan, Jaipur.

7. Tushti .P. Bakrania. "Impact of Social Media on College Students". International Research Journal on Advanced Science Hub, 2, Special Issue ICARD 2020, 2020, 236-239. doi: 10.47392/irjash.2020.126

8. Urfana Amin Moharken; S. Mufeed Ahmad. "Need For Learning Materials at Early Grades as Per Nai Talim in J\&K - An Empirical Study". International Research Journal on Advanced Science Hub, 2, Special Issue ICARD 2020, 2020, 139-148. doi: 10.47392/irjash.2020.110

9. Nepomnyaschy L, Waldfogel J. Paternity leave and fathers' involvement with their young children. Evidence from the American ECLSB. Community, Work \& Family. 2007;10(4):427-453.

10. Pancsofar N, Vernon-Feagans L. Mother and father language input to young children: contributions to later language development. $J$ Appl Dev Psychol. 2006;27(6):571-587.

11. Parker K, Wang W. Modern Parenthood: Roles of Moms and Dads Converge as They Balance Work and Family. Washington, DC: Pew Research Center; 2013. Available at: http://genderedinnovations.taiwan-gist.net/institutions/Modern Parenthood _ Pew Social \%26 Demographic Trends.pdf. Accessed May 28, 2019.

12. Rajhans P, Goinâ, Kochel RP, Strathearn L., Kim S. It takes two! Exploring sex differences in parenting neurobiology and behaviour. $J$ Neuroendocrinol. April 29, 2019.

13. Raeburn P. Do Fathers Matter? What Science is Telling Us About the Parent We 've Overlooked. New York, NY: Scientific American/Farrar, Straus, Giroux; 2014

14. Saraff, A., \& Srivastava, H. (2008). Envisioning Fatherhood: Indian Fathers' Perceptions of an Ideal Father. Population Review. 47, Number 1, 2008 retrieved $20^{\text {th }}$ January 2010 from http://muse.jhu.edu/journals/population_review/v047/47.1.saraff.pdf

15. Sarkadi A, Kristiansson R, Oberklaid F, Bremberg S. Fathers' involvement and children's developmental outcomes: a systematic review of longitudinal studies. Acta Paediatr. 2008;97(2):153-158.

16. Sriram, R, (2003), Subjective experiences of fatherhood and motherhood: Realities and Reflections , Unpublished PhD dissertation, Department of Human Development and Family studies, M.S. University of Baroda, Baroda

17. Sriram, R. ( 2008). Evidence of Change and Continuity in Fathering: The Case of Western India. Paper presented at Conference on Resilience and Transformation of Families in Asia, , organized by Asia Research Institute, National University of Singapore, 4-5 August 2008

18. Shannon JD, Cabrera NJ, Tamis-Lemonda C, Lamb ME. Who stays and who leaves: father accessibility across children's first 5 years. Parent Sci Pract. 2009;9(1-2):78-100.

19. Yogman M, Garfield CF; Committee on Psychosocial Aspects of Child and Family Health. Fathers' role in the care and development of their children: the role of pediatricians. Pediatrics. 2016;138(1):e20161128.

20. Yogman YW, Lester BM, Hoffman J. Behavioral and cardiac rhythmicity during mother-father-stranger infant social interaction. Pediatr Res. 1983;17(11):872-876 